\title{
Attilio Boriani, IUGS Vice-President (1992-1996) and Secretary General (1996-2002)
}

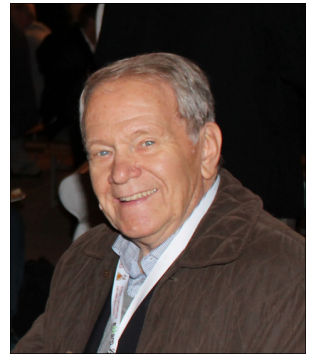

Attilio (Lio) Boriani, age 83, passed away on 12 March 2020 in Milan. The IUGS community knew Lio well because of his involvement with the Union in many capacities, most notably Vice-President (1992-1996), Secretary General (1996-2002), as well as President of the highly successful $32^{\text {nd }}$ International Geological Congress in Florence (2004).

Born in 1936 in Milan, Attilio Boriani graduated in 1960 from the University of Milan where he subsequently joined as a faculty member. Lio developed an intensive and continuous research career in plutono-metamorphic areas within programs coordinated by the Institute of Mineralogy and Petrology (later Department of Earth Sciences) of the University of Milan, originally as an Assistant Professor, then Full Professor and Director (Institute 1980-1982; Department 1988-1991) and also as an associate member of the Center for the Stratigraphic and Petrological Studies of the Central Alps of the Italian National Research Council (CNR). His personal research contributed significant relevant science to the understanding of the geological evolution of the Southern Alps. As a research leader he successfully guided students and collaborators in extra-Alpine areas such as Indonesia and the Republic of Benin in Western Africa.

A very active scientist, Attilio Boriani was an invited speaker and convener at many scientific conferences and was editor of several volumes of proceedings of national and international symposia throughout his career. He was a member of the editorial board of numerous national and international scientific journals. He published more than one hundred scientific papers and geological maps. Most of his publications dealt with the plutono-metamorphic basement complex of the Southern Alps, but also the Austroalpine and Pennidic units, the Indonesian Arc, and the Panafrican Event in West Africa. The overarching theme of all his research was the reconstruction of the processes leading to the origin and differentiation of the continental crust, from the formation of an accretionary terrane, through orogenic metamorphism, post-orogenic extension, mafic underplating, the origin of granitic magma, and the differentiation of the lower crust. In recognition of his many scientific achievements he was elected a member of the Accademia dei Lincei (Rome) and the Accademia delle Scienze (Turin).

Besides research and teaching, he contributed actively in the field of research management both at the national and international level. He was member and President of several committees of the Italian
National Research Council (CNR) for international cooperation in the field of Earth Sciences, including the Commission for International Relations. He was member of the Italian National Committee for Geological Sciences, Chairman of the Coordinating Committee of the Participating Countries of the International Lithosphere Program, President of the Società Italiana di Mineralogia e Petrologia, and Vice-President of the European Mineralogical Union. He was one of the founders of the European Journal of Mineralogy and member of its Managing Committee.

Attilio effectively contributed to the International Union of Geological Sciences in many ways. He was Vice-President (1992-1996) and then Secretary General (1996-2002), a position from which he resigned when appointed President of the $32^{\text {nd }}$ International Geological Congress (Florence). The $32^{\text {nd }} \mathrm{IGC}$ was a huge success. While attendance at previous IGCs was remarkable, the more than 7,000 Earth scientists, exhibitors, and guests who met in Florence set an all-time record as the highest number of participants ever for an IGC. Participants came from 120 countries and notably $75 \%$ were not Italian. This proportion of foreign attendees is the largest ever.

During his tenure as Secretary General, the IUGS released the document "International Earth Sciences in the $21^{\text {st }}$ Century" which listed thirty-two key recommendations geared to a better exposure of the geosciences to the public, an improved involvement of IUGS in international science programmes, and attention for better internal organization. Implementation of the document positively reshaped the Union in a manner that is still visible today. In recent years Attilio was again involved in the long-term planning of the Union by chairing the IUGS Strategic Planning Committee which in 2012 released the blueprint document for the development of the Union over the following few years.

Lio was a true gentleman and a connoisseur of culture. He was a diplomat and leader, capable of managing all situations with a dry sense of humor, but with surprising determination and an ability to stand his ground on matters of principle. He will be fondly remembered and missed for his ethical beliefs, leadership skills, and scientific achievements but most of all for his warm-hearted feelings toward his friends and colleagues.
Peter Bobrowsky Antonio Brambati William Cavazza Umberto Cordani 